\title{
Language and ethnography: a reply to Allard
}

\section{Luiz Costa}

\section{OpenEdition}

\section{Journals}

\section{Electronic version}

URL: https://journals.openedition.org/jsa/17003

DOI: 10.4000/jsa.17003

ISSN: $1957-7842$

\section{Publisher}

Société des américanistes

\section{Printed version}

Date of publication: 15 June 2019

Number of pages: $143-160$

ISBN: 978-2-902715-11-4

ISSN: 0037-9174

\section{Electronic reference}

Luiz Costa, "Language and ethnography: a reply to Allard", Journal de la Société des américanistes [Online], 105-1 | 2019, Online since 15 June 2019, connection on 05 September 2022. URL: http:// journals.openedition.org/jsa/17003 ; DOI: https://doi.org/10.4000/jsa. 17003

All rights reserved 


\title{
Language and ethnography: a reply to Allard
}

\author{
Luiz Costa *
}

It is a privilege to have The owners of kinship reviewed with such passion. Despite his critical opinion of the book, Allard has obviously been taken by it: he dissects it, wrestles with it, at times admires it, but ultimately cannot endorse it. The first part of his review is largely positive, praising what he understands to be the book's fascinating ethnographic contributions. But, in a surprising turn, the second part reviews an entirely different book, one that dismisses ethnography in favour of a naïve linguistics. This is no trivial methodological transgression, and I thank the editors of the Journal de la Société des américanistes for affording me the opportunity to reply.

I will focus on what appears to be the main offence: that I rely excessively on the semantics of Kanamari words, or on their conceptual aspects, in lieu of practice, and that this results in an over-rigid interpretation of Kanamari words (or concepts), particularly (but not exclusively) of the -warah. I will show that, despite paying lip service to "context," Allard extirpates my analyses from the ethnographic contexts in which they are embedded in order to make it seem as if I were trying "to elucidate an Amerindian concept [...] through a study of native language."

\section{What words do in an ethnography}

It is true that my ethnography includes an investigation of the Kanamari words which circumscribe and traverse the kinship processes. Allard dismisses these as being based on "dubious etymologies," but there is only a single timid (and ultimately abandoned) attempt at reconstructing an etymology in my book (p. 76-80). Etymologies point to histories of lexicalization and changing

* Universidade Federal do Rio de Janeiro [luizcosta10@gmail.com].

1. Unreferenced quotes are taken from Allard's review, published in this issue. Numbers in parentheses refer to pages in Costa 2017a. 
meanings, and concern linguistic relationships that speakers of a language may not explicitly (or even intuitively) be aware of. With the exception of -warah, discussed below, my analyses of the Kanamari language concern the content of conventional compositional expressions that function as lexemes. Such expressions are composed of non-compositional lexical and morphological elements that contribute meaningful information. Any Kanamari man or woman can reflect on how these elements are combined to form standardized expressions that describe social practices, relations and processes (e.g. p. 26-27). Sometimes these explanations can involve translation, but just as often they involve paraphrases internal to the Kanamari language (e.g. p. 149-150). I don't deal with etymologies, but reveal conscious meanings of words and how these meanings relate to social practices.

The lexemes I analyse and their semantic ranges map an ethnographic space: they are benchmarks around which I weave my ethnography of how the Kanamari transform predation into kinship via feeding and the ownership relation it generates. No conclusions are ever drawn from analyses of the lexemes. Rather, linguistic analyses invite the reader to follow me in unveiling the practices that occur in the vicinity of a lexical-semantic field. Allard questions their accuracy, but the reader is never asked to believe them on their own. Proof lies in the accompanying ethnography. Lexical-semantic description does not substitute for the ethnography, but draws the reader into Kanamari social praxis by revealing the idiom in which social relations and practices are spoken about.

My immediate Amazonianist inspiration for this approach is Peter Gow's study of Piro kinship. Gow typically encloses his analysis of Piro kinship within certain Piro or Ucayali Spanish words, thereby disclosing how kinship is understood by the people who live it. His method sometimes involves demonstrating how the meanings of a word differ from or resemble the meanings of related words (e.g. Gow 1991, p. 209-210, 2000; see also my book, p. 34-38); at other times he explores how the meanings of certain words find echo in the practices associated with them (e.g. Gow 1989, p. 575, 2001, p. 70, 79-81; see also my book, p. 25-29). ${ }^{2}$ We wouldn't understand how Piro kinship is lived without the judicious description of the idiom in which it is interpreted and conveyed, made and unmade, processed and conventionalized.

2. See also Gow $(1989,1991$, p. $153,162-163 ; 1997$, p. 44-45 ; 2000, p. 47, 49-50 ; 2002, p. 153-157). This is just a sample. The literary strategy of framing ethnography via semantic analysis is a basic aspect of Gow's work. Note also that Gow goes much further than I do, often using comparative etymologies as elements in ethno-historical reconstructions (Gow 2002, 2006, 2012, 2013). Here he benefits from available studies of a wide range of Arawak languages, which enable historical linguistics to be carried out. I find Gow's use of historical linguistics compelling, though I didn't attempt anything of the sort in my book, nor could I in the absence of comparative studies of Katukina languages (p. 76). 
What inspires me in Gow's ethnographic style is how lexical-semantic description, rather than being an aside provided for the sake of comprehensiveness, or a detour from the description of social processes, is vividly welded into the very ethnography of the social processes that he foregrounds. Allard notes that I conduct a "fascinating dialogue" with Gow, but he doesn't notice that my much-maligned focus on the meaning of Kanamari words and their articulation with practice is part of this dialogue. Perhaps he doesn't notice this because, although I am inspired by Gow's style, the analysis of the semantic reach of key words or phrases is as old as ethnography itself. My guess is that Gow's main inspiration here is Malinowski, ${ }^{3}$ who had written that "the linguistic problem before the ethnographer is to give as full a presentation of language as of any other aspect of culture" (Malinowski 1935, p. vii), but also, evidently, that "it is impossible to translate words of a primitive language or of one widely different from our own, without giving a detailed account of the culture of its users and thus providing the common measure necessary for a translation" (Malinowski 1923, p. 470). For a few famous examples from lowland South America, we have Overing Kaplan's (1975, p. 69-87) elucidation of the concept of chuwaruwang as part of her account of Piaroa kinship; Crocker's (1985) cartography of Bororo shamanism through the concepts of bope, aroe, raka and others; and Vilaça's (1992, p. 49-63) explanation of Wari' cannibalism through an introductory discussion of the concepts of wari', karawa, kwere- and jam; among countless more.

Allard surely knows this, which might account for his uneasiness with my reference to Evans-Pritchard's perceptive but uncontroversial claim that ethnographies depend on our understanding of "a few key words." After all, he does not want to criticize him for, say, "draw[ing] very hypothetical conclusions from the analysis of linguistic constructions." So he recommends that we understand Evans-Pritchard's statement in context. (I suppose it is easier to accommodate context where renowned anthropologists are concerned.) He may have written that, but he was also interested in practice. Well, of course he was. We all are. This did not prevent him from opening Nuer religion with a chapter on the semantics of the Nuer word kwoth, which he translates as "God" (Evans-Pritchard 1956). The first pages of that book compare kwoth with words from Latin, Greek and Hebrew, and consider how kwoth behaves in different grammatical environments, semantic roles and in conjunction with a range of qualifiers. Evans-Pritchard explains how the Nuer associate 'God' with other words and how 'God' is refracted through experience. This method is repeated throughout Nuer religion for different words in the Nuer language, their usages

3. Gow (2001, p. 19-28) has discussed his method as a reconciliation of Lévi-Straussian and Malinowskian approaches. 
and implications. Semantic analysis of key words makes ethnography compelling and ethnography galvanizes analyses of language.

It is unnecessary to demonstrate that what applies to Nuer religion is pervasive in Evans-Pritchard's oeuvre. To stick to his ethnography of the Nuer, suffice to recall the discussion, in The Nuer, of the pragmatic meaning of cieng ("homestead, hamlet, village and tribal sections of various dimensions"), or, in Kinship and marriage among the Nuer, of the semantic meaning of rual ("incest and misfortune"). Again, there is nothing exceptional about any of this. I quoted Evans-Pritchard only because he very explicitly articulated an understanding of a "few key words" with ethnographic analysis; indeed, this, according to him, is what "every experienced fieldworker knows." Relying on Evans-Pritchard's acumen, I added: "These [key] words can only be learned by directly engaging with the language and the people who speak it over a long period of time. Evans-Pritchard was conceding that our ethnographies often hinge on a fleeting moment in which we learn the meaning of a word, but these moments will remain missed opportunities for ethnographers who do not then take the time to map out all of their consequences through careful ethnographic investigation" (p. 3, emphasis added). Instead of being a shortcut to reading "patterns of thought directly from the analysis of language," key words trigger analyses of social processes. ${ }^{4}$ Indeed, they are part of these very processes, the categories in which they are invested. Lexical analyses are always mobilized as vantage points for surveying ethnography, since in the absence of extra-linguistic evidence they would, indeed, be worthless for anthropological analysis. Allard may feel that my book is not as effective as the outstanding ethnographies I refer to above, or that my use of semantic analysis alongside ethnographic explication falls short of established anthropological standards, and that's fine; but my method is hardly so exotic and perverse as to upset the "purpose and nature of our work as anthropologists."

\section{(-)Warah does not mean 'body-owner'}

I don't agree with Allard that -warah is the "central concept" of my book, nor that it is somehow more "key" than the many other lexemes I analyse, which together constitute a meaningful set entwined with the kinship process. ${ }^{5}$

4. They do more than this: key words trigger fieldwork protocols, prompting us to be attentive to occurrence and contexts of use.

5. Allard's portrayal of my book as being about 'concepts' is supported by scare-quote references to the word "concept" and corresponding page numbers for my book (only two pages, actually), with no context as to how the word "concept" is used in the pages referenced. Thus he claims that "Costa explicitly presents his work as the study of a 'concept' (p. 223)," but here is what I wrote: "This book has been concerned with the Kanamari concept of feeding and the dependence it generates in others, a dynamic I call 'the feeding relation'." It would 
However, I can only understand Allard's motivation for criticizing me when he turns to my translation of -warah as 'body-owner,' which he feels compromises the book. I will justify the translation below, and also question why Allard finds it necessary to latch on to a translation, prescinding it from the concomitant ethnography in order to more advantageously criticize it.

Before doing so, however, I had best state it outright. The Kanamari lexeme (-)warah does not mean 'body-owner.' I do not claim that it does. Likewise, 'body-owner' is not how the Kanamari translate (-)warah, nor did I coin the composite word to reveal some sort of covert but 'real' translation of (-)warah, one that I would infer or deduce that the Kanamari posit but cannot express. Finally, the Kanamari (-)warah is not a denotative lexeme with a single, stable and unchanging real-world corollary defined ostensively, but a word the referents of which change depending on how it is grammatically encoded, contextually modulated $^{6}$ and interpretatively resolved.

There are four senses of (-)warah that I discuss in my book:

1. - Warah is a possessive noun phrase (PNP) that describes a salient pattern of relations that are inferred from and construed as immanent to the world. It defines the singular in relation to multiple, autonomy in relation to dependency, the whole in relation to parts, owner in relation to owned, and source in relation to derivation (p. 57). Grammatically, in a construction such as $X$-warah, -warah can be defined as that which the argument $(' X$ ') is a part of, is derived from, and/or belongs to (p. 60). It applies to contexts in which something emerges as singular in relation to the many parts that compose it (e.g. trunk in relation to rest of tree, main channel of a river system in relation to its tributaries and headwaters), or as composite but autonomous in relation to dependent elements, which may themselves be composite or simple (e.g. a parent tree in relation to derived species, a major river basin in relation to connected minor river basin). I demonstrate this usage of -warah through examples on p. 60-62, 140-148 (in the latter section in terms of hydrology, always relating sense 1 of -warah to settlement pattern and political structure, as in sense 2 below). I translate this sense of -warah as 'body-owner.'

2. In some cases, the connotations of -warah are interpreted as emerging from a feeding relation, and the effects of magnification and dependency that feeding generates in the parties involved. In these cases, in which -warah is grammatically identical to (but ethnographically different from) sense 1, I also translate it as 'body-owner.' I provide ethnographic accounts

have been more accurate to claim, based on that sentence, that I explicitly present my work as the study of a "dynamic" or a "relation." Note also that one of the two occurrences of "concept" singled out by Allard does not concern the "central concept" of -warah at all.

6. On contextual modulation of meaning, see Cruse (1986, p. 52-53). 
of many of the different relations in which 'body-owner' and 'dependent' are equivalent to, respectively, 'feeder' and 'fed': owner and pet (p. 30-41, 48-58); shaman and familiar spirit (41-58); mother and child (chapter 3); chiefs and followers (p. 137-168); the Brazilian State and the Kanamari (p. 168-173; Costa 2017b). Such relations are not always interpreted as instances of -warah; they are so interpreted when the speaker wishes to draw attention to the supplementary productive and distributive capacity of one party in relation to the other (p. 28-29), for which I provide examples and case studies (e.g. p. 70-74). ${ }^{7}$

3. While (1) and (2) are PNP realizations of -warah, the word warah also occurs as a verb (I here write it without the hyphen, indicating it is no longer a bound lexeme; see $\mathrm{p}$. xx). In these cases, it expresses predicative possession, and has the general meaning of 'to have,' which I tentatively propose is a denominal verb derived from senses 1 and 2 (p. 75-78). I show that the verb warah is mostly restricted to contexts in which what one has or owns is of non-Indigenous origin (p. 76-80). In brief, one 'has' (warah) Western merchandise, whereas one is an $X$-warah as a consequence of 'body-owning' pets, dependent kinspeople, shamanic familiar spirits and so forth.

4. The word warah also occurs as a non-predicative noun, in which case it refers to 'Western merchandise.' Very briefly, western merchandise as a bulk concept is called warah because it is posited as a mysterious manifestation of the power of the whites, that which makes them into $X$-warah (in sense 2) of (specific items of) merchandise (p. 78-80). I describe that both senses 3 and 4 are linked to Kanamari interpretations of and relations with

7. It is frustrating to have to convince potential readers that my book is an ethnography (rather than, as Allard would have it, a "phrasebook"), since it will be more than obvious to them. But I am accused of "thinning" my ethnography in order to move directly "from thought to language," so I will draw attention to just one of the instances of $X$-warah in this second sense that I single out for ethnographic exegesis: the relation between mother and child. For this relation, I describe theories of conception and practices observed during pregnancy (p. 100-101); the effects of the foetus on the practices of future parents and coresidents (p. 102-103, 106-110); practices of contraception and abortion and native explanations for them (p. 104-106); couvade practices and reactions to the blood of the newborn (p. 106-110); how blood behaves in circulation and exsanguination and how it relates to the soul and to alterity (p. 110-114); how feeding counters the effects of perinatal bleeding (p. 114, 117-120, 120-122); how the couvade relates to the practice of homicide seclusion (p. 114-117); how feeding gives way to relations of mutuality, interpreted under the aegis of commensality and love as the child ages (p. 122-128, 148-154); how the life cycle moves a child from a state of dependence to one where others depend on him or her, and thus how the mother-child bond differs from that between owner and pet (p. 125-128); how fosterage is tied to feeding practices and the effects that it generates (p. 128-135); and so forth. Each of these themes conceals more nuanced descriptions that I cannot enumerate here. I have also not listed my comparative counterpoints that understand Kanamari practices in light of Amazonian anthropology and vice versa. 
the whites, and provide ample historical and ethnographical analyses of how these senses of warah differ from and relate to senses 1 and 2 (p. 80-96).

Although I explain the linguistic usages and ethnographic manifestations of all these senses of (-)warah, my book is only really concerned with sense 2, which is defined by an ethnographic and a linguistic constraint (p. 65). The ethnographic constraint is that my book seeks to elucidate the dynamic of feeding and dependence, and hence it is primarily concerned with instances of -warah that the Kanamari deduce in terms of feeding and dependence (a condition exclusive to sense $2^{8}$ ). The linguistic constraint is that -warah occur in a PNP (a condition that applies to senses 1 and 2). The linguistic constraint is only relevant insofar as it encodes a relation observed ethnographically, and not vice versa.

\section{The concept of the 'body-owner'}

Allard really dislikes my translation of $X$-warah (senses 1 and 2 above) as 'body-owner.' Here are some of his reasons why:

1. He is "convinced [that] with the evidence [I] provide it is impossible to claim that: "'body," "owner," and "chief" are imperfect glosses for what, in the Kanamari language, is one concept." "This is in part because of the heterogeneous meanings of (-)warah and because some of the instances of -warah or warah that I discuss might be cases of homophony and I was duped. 2. His imaginary pragmatics of -warah (frustratingly without recourse to the evidence I provide, which had convinced him of my error) assures him that the word must be translated according to context.

3. 'Rendering some of the semantic range of '-warah' as 'body' is problematic because [body] has connotations of individuality and wholeness in European languages, whereas [owner] is essentially a relational concept."

4. Having claimed that I shouldn't look for a stable translation to -warah, Allard (somewhat confusingly) then proposes that I "could perhaps have better conveyed [my] point by talking of the 'trunk-owner', insofar as 'trunk' implicitly always implies a contrast with the branches (of a tree) or limbs (of a body)." According to him, translating -warah as 'body-owner' is like translating the English word 'chair' into the French président-chaise, since 'chair' can sometimes mean 'a seat of office and authority' and at other times 'a seat, especially for one person, with four legs for support, a rest for the back and (often) rests for the arm.'

8. See senses 3 and 4, which are interpreted in terms of predation and the assumed cannibalism of the whites (p. 88-96). See also how predation sustains -warah relations in myth, and how myth narrates how predation modulates into feeding (p. 190-194). 
Regarding the first critique, Allard relies exclusively on the use of the word 'concept' in p. 2 of my book. The word appears there as part of a vignette I use to introduce the reader to the ethnography and to acclimatize her to the sorts of issues I will be addressing. I recount that, in the early months of fieldwork, I tried to obtain from my Kanamari grandfather, Poroya, a statement on the bodies of ancient chiefs, whom I had been told were beautiful and incorruptible. I put together a phrase using the word -warah for 'chief' and the word boroh for 'body.' It turns out, however, that the latter word actually means 'corpse.' Poroya explained to me that the Kanamari word for 'body' is -warah, which left me dumbfounded. Perceiving my incomprehension, Poroya told me in Portuguese that "our body is our owner and our chief." This is a story of how, early on in my research, I learned one of the words that would accompany my ethnography. It is as part of this introductory exchange that I write that "'body", 'owner,' and 'chief' are imperfect glosses for what, in the Kanamari language, is one concept" (p. 2).

Allard accepts that Poroya's explanation "is indeed a remarkable fact," but protests that it "was intended to solve a problem of vocabulary rather than as a comment on the bodily and political order of things." I do not claim otherwise. The evidence for the non-semantic implications of -warah does not, of course, come from this exchange, which only drew my attention to usages and practices associated with (-)warah. The evidence for its non-semantic implications-its role in the "bodily and political order of things" - is presented throughout the book (specially Chapter 4). Poroya's explanation nonetheless provides us with a native affirmation of the semantic unity of -warah, which allows us to discard the question of whether we are dealing with homophony, polysemy or whatever.

Allard doesn't think that this is right: "[H]aving claimed that '-warah' is 'one concept', Costa is at pains to account for some heterogeneous uses of the word. [...] While '-warah' designates primarily an owner in relation to what is owned, $\left[{ }^{9}\right]$ 'warah' can also be used as a verb meaning 'to have' in general (as possession rather than ownership, p. 75-77), and 'warah' is a noun that refers to Western merchandise (which Kanamari people 'possess' rather than 'own', p. 78)" (but which, I might add, white people 'own' rather than 'possess' [p. 91]). However, nowhere in my book do I claim that all of these senses comprise "one concept." What I claim to be one concept in the passage that bothered Allard is sense 2 of -warah, the only one that can be translated, inter alia, as 'body', 'owner', 'chief.' One of the ways I demonstrate that sense 2 is one concept is, precisely, by comparing it with senses 1, 3 and 4. Again, this comparison is not confined to language, since I describe ethnographically how these differences are understood by the Kanamari as applying to distinct

9. Why not "primarily" a body in relation to what is embodied? 
domains (kinship, exchange, the whites, landscape) and how they navigate these domains through practices that include pet-keeping (p. 30-41), animal husbandry (p. 80-96), relations with government agents (p. 84-87, 173-184, 201-210), shamanism (p. 41-58), etc.

However, I appreciate that I was perhaps timid regarding the conceptual unity of senses 1-4 of (-)warah, in large part because I was not remotely interested in "the production of concepts out of ethnography," much less in doing anything as outrageous as building a "philosophy out of a vocabulary." Without falling into the trap of discussing what a "concept" (or, for that matter, a "practice") might be, much less how concepts (and practices) relate to language, it is obvious that senses 1-4 of (-)warah comprise "one concept" in the very general sense of being a "convenient capsule of thought that embraces thousands of distinct experiences and that is ready to take in thousands more" (Sapir 1921, p. 13). (-) Warah is a concept that converges on notions of ownership, belonging, source and prominence. This convergence is fairly typical of notions of 'body' and 'owner' throughout Amazonia (see below). The overlap between the meronymic relations of the body and the grammar of possession is furthermore common worldwide (Aikhenvald 2013, p. 9-13; Cruse 1986, p. 157). Similarly, theories of grammaticalization show how attributive possession (i.e. my 'ownership') is often derived from source schemas cross-linguistically (Heine 1997, p. 144156). What the Kanamari seem to have done is to use senses 1 and 2 of -warah to take in (and synthesize) thousands of experiences associated with the whites, giving rise to senses 3 and 4 (p. 75-96). In my vocabulary, they use relations of ownership to interpret new relations of possession (p. 75-76) that derive from this encounter. ${ }^{10}$

\section{Fetishizing translation}

In his second objection, Allard insists that the word -warah must have contextual translations. I agree with him:

Portuguese-speaking Kanamari admit their difficulty in translating -warah [senses 1 and 2] in a consistent manner. Instead, they provide a number of contextual glosses that take into account the nature of the argument. These include the Portuguese for "trunk" (tronco), "chief" (chefe, cacique, tuxaua), "big" (grande), and "the place of" (o lugar de, i.e., the origin of something or someone). However, the most common and conceptually most wide-ranging and flexible glosses are "body" (corpo) and "owner" (dono), as Poroya first revealed to me when correcting my clumsy question (see Introduction). In most cases when I asked bilingual Kanamari to translate -warah, I was told that it means either "body" or "owner" or

10. Though I do not claim that senses 3 and 4 derive from inter-ethnic contact, only that they are at present restricted to this domain (p. 78). 
that both translations would be correct. Although contextual glosses are necessary in pragmatic circumstances, I submit that, in the Kanamari language, they make little sense. When it occurs in a noun phrase, -warah always designates an asymmetrical relation that can be synthesized as either the "body of" or "owner of," but also as "chief of," "main tributary of," and so forth. For the sake of brevity, I shall render -warah as "body-owner [of]," a composite of the two most common translations for -warah. (p. 62)

Allard is nonetheless convinced that -warah has a meaning in Kanamari which is equivalent to its contextual translations, and that this meaning must be pretty much what "body" and "owner" (and presumably the other translations) mean in Portuguese (or French or English), as per his third objection. As I note in the passage quoted above, the problem is that native translations are by no means systematic, nor would they map easily onto Portuguese terms and their semantic ranges. Just as a person may translate Poroya-warah as 'Poroya's mother' (mãe do Poroya ${ }^{11}$ ), they may as well in other contexts say that she is 'Poroya's owner' (dona do Poroya, when Poroya's dependence on her is stressed, for instance) or that she is 'Poroya's body' (corpo do Poroya, when her intimacy with and care for Poroya is stressed, for instance). Poroya-warah captures all these senses, and others, at once. Translations are consequently by no means consistently context-sensitive for all bilingual Kanamari: some are more mindful of the fit of a given translation to the exigencies of the Portuguese language, others are more committed to a stable translation (say "body," corpo) irrespective of whether it sounds correct in the target language. This is why, as I note, the Kanamari often say that both or either "body" and "owner" are correct translations, and that these translations are the most flexible and wideranging, though one or the other or neither may be the 'best translation' (for Allard, if not for any of my interlocutors). ${ }^{12}$

What I argue is that none of the translations provided by the Kanamari for tokens of $X$-warah can capture its meaning, since it doesn't have a simple translation into standard Portuguese vocabulary. It might be interesting to observe

11. In these cases, Kanamari typically provide a Portuguese paraphrase such as é porque é a mãe do Poroya ('it is because [she] is Poroya's mother'). The Kanamari kinship term for 'mother' is niama and a-warah PNP constructions is only used for a mother-child bond in contexts in which an aspect of sense 2 is to be conveyed (p. 122-123), or when a foster mother is referred to (p. 133).

12. I wonder how Allard would deal with the shaman. The shaman has familiar spirits which he stores in a container (p. 45-46), but he also has/is (see the problem?) the spirit-substance (dyohko) that suffuses his body (p. 42-43). It is in his body and is what he externalizes and manipulates to actualize shamanic power. Accordingly, one possible term for the shaman is dyohko-warah (p. 59). What translation would convince Allard here? Is the shaman the owner of the dyohko or its body? Or take the chief of a peccary herd, also a shaman, who carries in its gut a bezoar which the Kanamari say is its dyohko. Is the peccary the body or the owner of the bezoar in a "realistic linguistic situation"? 
when a translation is preferred and by whom it is preferred, but this fetishizes translation - as if the true meaning of the word were the translation, and not its language-internal contrasts. While Allard is preoccupied with translation, he has nothing to say about the much more elaborate and detailed analyses of the Kanamari words that signpost my ethnography via comparisons that are internal to the Kanamari language, and which delimit a lexical and semantic field that is dynamically involved in the processes that I describe ethnographically. ${ }^{13}$

But since Allard ignores this work and builds his critique on a translation, it is worth asking: why translate native words at all? Translation of foreign words serves a number of purposes in ethnographic writing. It can be a shorthand, as it were, which tries to be as effective as possible in terms of ethnographic yield and literary intelligibility, but which ultimately only provides stand-ins for words the meanings of which are irreducible to a given translation. It would simply be too cumbersome for the reader if I retained Kanamari words throughout. Since meaning furthermore depends on extra-lexical factors, it would also require that the reader keep in mind grammatical relations of the Kanamari language. This would not only demand too much from the reader, it would also be a sign of laziness on my part. But translation has another advantage: it draws the reader into a field of meanings that relates a chosen stand-in to words in the target language or in anthropological jargon. This is why I translated -warah as 'body-owner': frequency and consistency of occurrence of 'body' and 'owner' as translations, and the fact that this allows me to interpret and discuss -warah in light of Amazonian theories of the Amerindian 'body' and the 'owner', both of which are pertinent to an understanding of -warah, and which are themselves affected by the data that -warah contributes.

\section{What is a body?}

This brings me to Allard's baffling third objection. I find it hard to see how an Amazonianist - or an anthropologist, for that matter - could object to my use of

13. I've already pinpointed how $X$-warah in sense 2 is defined by its contrasts with senses 1, 3 and 4. For further intra-linguistic analyses, see: on the contrast between $w u$ ('to love') and owu ('to want') (p. 34-38); on how ayuh-man ('to feed') differs from other words incorporating ayuh ('to need') (p. 25-29, 150); on how ayuh-man differs from da-wihnin-pu ('commensality') (p. 39-41, 145-148); on how -wihnin ('kinspeople', 'a cluster') relates to -wihnin tam ('close kin'), -wihnin parara ('distant kin') and -wihnin tu ('non-kin') (p. 146152); on how -wihnin differs from ayuhtunin ('a lot') (p. 149-154); on how mimi ('blood') lexically differs but semantically overlaps with -ikonanin ('soul') (p. 110-114); on how mimi aboawa ("new blood") relates to mimi dioknin ("pungent blood") (p. 118); on other uses of $\operatorname{diok(nin)}($ p. 42, n. 17; p. 103, 195); on how the suffix -ok generates different denominal verbs (p. 117). This sample should suffice to show that translation is less important in my work than determining the semantic space that a given word occupies in the Kanamari language by studying patterns of contrast and convergence, reflection and use. 
'body' in the composite 'body-owner' on the grounds that 'body' connotes individuality and wholeness in European languages. There are so many prejudices involved in this claim that it is difficult to know where to start. For one, it simply isn't true. In English, 'body' derives from an Old English word that denoted not only the trunk of humans and animals, but also more generally the main or principal part of a thing (and hence not 'wholeness', but always the mainstay of a 'whole'). Contemporary 'body' can refer to a collectivity or corporation of persons, things or ideas, as much as to an individual (as when Allard uses the expression "growing body of scholarship" in his review). The same is true of the Portuguese word corpo, which derives from the Latin corpus. The idea of a 'body politic' dates from at least the middle ages and frames a typically European political philosophy (see Kantorowicz 1957 for a classic discussion). Even when 'body' is coterminous with 'individual', it denotes a composite set made up of multiple parts and their interrelations (which is what a "whole" is), and hence a singularity composed of relations internal to it. In European languages, 'body' is as much a "relational concept" as 'ownership.'

Secondly, for anthropology, as for all of the humanities and sciences, the idea that the body precludes its relational constitution, or that it can be isolated from its environment (including other bodies), goes against all available empirical evidence. It would be impossible to discuss here the very many (ancient and venerable, as well as modern and cutting-edge) approaches to the body as dynamic and relational, rather than discrete and individualized. I am afraid that convincing my critic of this would take me well beyond the confines of this reply (see Farquhar and Lock [2007] for an introductory reader).

Finally, it is surprising to read that my use of the English word 'body' must have connotations which are ostensibly typical of "European languages"- as if by writing in a European language I were unable to convey Indigenous Amazonian meanings, a state of affairs that would render anthropology impossible. As Allard must know, a recognition of the centrality of the 'body' for native Amazonian people during the 1970s is Amazonian anthropology's coming-ofage moment, its emancipation from Africanist models of 'primitive' society, North American culturalist models of acculturation and the like. Pioneering statements of the meanings and usages of the body in Amazonia include Overing Kaplan (1977) and Seeger, DaMatta, and Viveiros de Castro (1979), but it's no exaggeration to say that pretty much all subsequent anthropological studies of Amazonian societies have dealt with the body and processes related to it in one way or another. The body is the inescapable theme in Amazonian anthropology, whether it emerges as an index of and target for kinship relations (e.g. Gow 1991; McCallum 2001; Overing Kaplan 2003), as the seat of knowledge and capacities (e.g. Seeger 1981; Kensinger 1995), as a focus of controlled or uncontrolled transformation (e.g. Taylor 1996; Vilaça 2005), as a bundle of 
affects that defines a perspective (e.g. Viveiros de Castro 1996), and so forth. Though Allard may intuitively believe that in European languages the words for 'body' do not imply relations, he would have to deny all scholarship on lowland South America to argue the same for concepts of the body in the region. Surely, a positivist, even a "vulgar" one, has to take this evidence into account. Allard recognizes that my book "seeks to advance" debates on ownership in Amazonia, but he ignores that my specific contribution to these debates involves showing how 'owner' and 'body' merge. The Kanamari focus on feeding articulates the theme of the 'owner' with kinship and the construction of bodies through relations of dependence that gradually become relations of conviviality. This is clearly stated throughout; I never write of 'the body' except with the connotations that the 'body' has in Amazonian scholarship and Indigenous discourse and practice (p. 2-4, 13-17, Chapter 3, et passim). If there is a theoretical point to be made here, it is that 'body' and 'owner' are themes that must be investigated together. ${ }^{14}$ This is perhaps all the more pressing in the context of the Panoan-, Katukina- and Arawá-speaking neighbours of the Kanamari, where the body is conceptualized through a complex topology of exteriority and interiority, container and contained, whole and part, owner and owned. ${ }^{15}$ The Arawá cognates abonoi (Paumari), abono (Jarawara, Banawa) and so forth designate the 'body-soul', hence exteriority and interiority, but also the main part of a thing in relation to other parts (Bonilla 2007, p. 145-149; Maizza 2014, p. 503) and the "spirit owner" of animals and plants (Aparício 2019, p. 229-230). The Marubo conceive of the body as a longhouse inhabited by a variable number of 'doubles' (Cesarino 2011, p. 35-36, 53-54), and one of their words for the 'body' (kaya) is also used for the main tributary of a river system, the trunk of a tree-in short, the main extension of a given configuration, which is also how it comes to mean 'chief' (ibid., p. 34, n. 2). The Marubo concept of 'owner' (ivo) can likewise denote the 'chief', the master of a longhouse in relation to its residents, or the spirit master of animal species (Cesarino 2016). There is a semantic overlap between 'body' and 'owner' even in the absence of lexical identity.

For the Biá River Katukina, who speak a dialect of the same language as the Kanamari (p. 10-11), the word wara denotes: the living body; a family of spirits linked to plants and animals; the origin of something; and 'fruit', i.e. what is derived from a tree (Deturche 2009, p. 296). When the suffix -hi is added to wara, it denotes the 'possessor of something' or the 'owner' of a ritual (waik-wara-hi,

14. See (p. 62), passage reproduced above, where I observe that the most adequate translation for - warah would be 'body-owner [of]', though I suppress the adposition for the sake of brevity. However, the phrase "body-owner of" recurs throughout the book.

15. None of these senses of the 'body' is exclusive to southwestern Amazonia. On the body as container, for instance, see Lévi-Strauss 1985; Hugh-Jones 2001. 
'owner of song') (Deturche 2009, p. 294). For the Kanamari, the owner of rituals, who is usually also a 'subgroup chief' (p. 154), is called nohman, though he can also be called by a -warah PNP that takes the name of the relevant genre of songs as its argument (p. 216). In Biá River Katukina, in contrast, nohman or nohmanhi designate the 'chief' (which in Kanamari is -warah) or the nonIndigenous 'boss' rather than the ritual sponsor (Deturche 2009, p. 111, 159). There is an evident ethnographic field that is common to the Kanamari-Katukina, involving ownership, the body, source-derivation and ascendancy over ritual functions and village life. This field is linguistically mapped by words that are related to the Kanamari -warah, warah and nohman, and to the Biá River wara, -warahi and nohman(hi). Far from being an ethnographic anomaly, this sort of pattern and the relations it communicates are common to a number of people in the Juruá-Purus region, speaking languages from at least three different families. Much of Allard's "surprise" at the implications of my analyses probably stems from his lack of familiarity with the pertinent ethnographies.

Perhaps I was overly pessimistic about the possibility of carrying out etymological analyses. Itaquaí Kanamari (which I studied) and Biá River Katukina are dialect extremes of Katukina-Kanamari, situated at the western and eastern limits of the region in which the language is spoken. A superficial analysis suggests that the Kanamari -warah synthesizes semantic aspects of the Biá River wara and -warahi, as well as being a lexical compromise between the two. Furthermore, Biá River wara exists in Kanamari as the verb 'to be born' (see 'source-derivation') (p. 105, n. 4), and-warahi exists in Kanamari in the form -mowarahi, which refers to 'nameless ancestors' (-mo is a locative for fixity; on the meaning of -mowarahi see p. 166-167, and Costa 2007, p. 80, 102-13). Furthermore, the Kanamari word warapikom means 'wild fruit', but it is rarely used in the Itaquai (where the name of specific fruits takes precedence), though it is very common among the Kanamari living to the east, where it also denotes a ritual complex occurring during the fruiting season (Labiak 2007) (p. 215216). There may be further clues in the dialect variants spoken in-between the Itaquaí and the Biá. The role of nohman as a further variable may be key here, particularly since the word is also found in some Panoan languages (though all specialists agree it is a borrowing from Katukina languages), where it either designates ancestral spirits or is a vocative term which spirits use to refer to the souls of humans who participate in ritual (Erikson 2004; Matos 2014, p. 151).

\section{Président-chaise and trunks}

Finally, translating -warah as 'body-owner' is obviously not the same as translating the English 'chair' into the French président-chaise. In the former case we have two predicative nouns, whereas in the latter meaning differs with valency: one must be président of something, but a chaise is not necessarily 
of anything. Furthermore, the term 'chair' obviously has the primary historical and conceptual meaning of 'seat of a certain type' and it is only through metonymy (a common process of semantic change) that it has come to refer to a président, i.e. one who sits in the chair, or the 'chairperson'. The genderneutral 'chair(person)' (for président) is actually quite recent: until the 1980s, 'chairman' or 'chairwoman' were more common. Similar difficulties apply to the meanings of 'head' as 'part of body' and as 'leader', the latter meaning borrowing from the ascendant place of the former in the structure of the body. The translation of -warah as 'body-owner' captures the synergy of the meanings of 'body' and 'owner' in Amazonia: both imply relations, and neither meaning is anterior (as far as we can know).

'Trunk-owner' presents another problem. 'Trunk' is a possible translation of -warah where the salience of the trunk or torso vis-à-vis the rest of the tree, human or animal is referred to (sense 1), but it is an insufficient translation because -warah can also denote a parent tree in relation to trees derived from it, or a person in relation to humans, animals and spirits dependent on him or her (chief, mother, owner of pet, shaman) (p. 60-65). Furthermore, the encompassing level eclipses the encompassed, so that a woman is the -warah of her pet but no one refers to the trunk/torso of that pet as the -warah of its appendages (p. 63-64, n. 5). In other ethnographic contexts, however, the word for 'chief' means something like 'mainstay', and hence maintains a semantic relation to 'trunk.' The idea of the chief as a 'mainstay of people' has been brilliantly described by Guerreiro (2015) among the Kalapalo of the Xingu (226). Indeed, the association between an arboreal and a chiefly idiom (a "botanical and sociopolitical relation") is as common in the Xingu as in the Juruá-Purus, despite their immense ethnographic differences (Maizza 2014; Fausto 2017; Shiratori 2018; Aparício 2019). Although Allard has doubts, it in fact recurs throughout Amazonia (e.g. Rival 1993; Kohn 2013).

\section{References cited}

Airhenvald Alexandra

2013 "Possession: a cross-linguistic perspective," in Alexandra Aikhenvald, and Robert M. Dixon (eds.), Possession and ownership. A cross-linguistic typology, Oxford University Press, Oxford, p. 1-64.

Aparício Miguel

2019 “A relação banawá. Socialidade e transformação no Arawá do Purus,” Ph.D. Thesis, Social Anthropology, Universidade Federal do Rio de Janeiro.

Bonilla Oiara

2007 "Des proies si désirables: soumission et prédation pour les Paumari d'Amazonie brésilienne," Ph.D. Thesis, Social Anthropology, École des hautes études en sciences sociales, Paris. 
Cesarino Pedro

2011 Oniska. Poética do Xamanismo na Amazônia, Fapesp, São Paulo.

2016 "Doubles and owners: relations of knowledge, authorship and property among the Marubo," in Marc Brightman, Carlos Fausto, and Vanessa Grotti (eds.), Ownership and nurture. Studies in native Amazonian property relations, Costa Luiz Berghahn Books, Oxford/New York, p. 186-209.

2007 "As faces do jaguar: parentesco, história e mitologia entre os Kanamari da Amazônia occidental,” Ph.D. Thesis, Social Anthropology, Universidade Federal do Rio de Janeiro.

2017a The owners of kinship. Asymmetrical relations in Indigenous Amazonia, HauBooks, Chicago.

2017 b "Becoming Funai': a Kanamari transformation," in Hanne Veber, and Pirjo Virtanen (eds.), Creating dialogues. Indigenous perceptions and changing forms of leadership in Amazonia, University of Colorado Press, Boulder.

CROcker Jon Christopher

1985 Vital souls. Bororo cosmology, natural symbolism, and shamanism, University of Arizona Press, Tucson.

Cruse David Alan

1986 Lexical Semantics, Cambridge University Press, Cambridge.

DetURChe Jérémy

2009 "Les Katukina du Rio Biá (état d'Amazonas-Brésil): histoire, organisation sociale et cosmologie," Ph.D. Thesis, Social Anthropology, université Paris Ouest Nanterre La Défense, Nanterre.

ERIKSON Philippe

2004 "La face cachée de l'ancestralité. Masques et affinité chez les Matis d'Amazonie brésilienne," Journal da la Société des américanistes, 90 (1), p. 119-142.

EvANS-PRITCHARD Edward

1956 Nuer Religion, Oxford, Clarendon Press.

FARQUHAR Judith, and Margaret Lock (eds.)

2007 Beyond the body proper. Reading the Anthropology of material life, Duke University Press, Durham.

Fausto Carlos

2017 "Chefe jaguar, chefe árvore: Afinidade, ancestralidade e memória no alto Xingu," Mana. Estudos de Antropologia Social, 23 (3), p. 653-676.

Gow Peter

1989 "The perverse child: desire in a native Amazonian subsitence economy," Man (N.S.), 24, p. 567-582.

1991 Of mixed blood. Kinship and history in Peruvian Amazonia, Clarendon Press, Oxford.

1997 “O parentesco como consciência humana: o caso dos Piro," Mana. Estudos de Antropologia Social, 3 (2), p. 39-65.

2000 "Helpless - the affective preconditions of Piro social life," in Joanna Overing, and Alan Passes (eds.), The Anthropology of love and Anger. The aesthetics of conviviality in native Amazonia, Routledge, London/New York, p. 46-63. 
2001 An Amazonian myth and its history, Oxford University Press, Oxford.

2002 "Piro, Apurinã and Campa: social dissimulation and assimilation as historical processes in southwestern Amazonia," in Jonathan Hill, and Fernando SantosGranero (eds.), Comparative Arawakan histories. Rethinking language family and culture area in Amazonia, University of Illinois Press, Urbana/Chicago, p. 147-170.

2006 “'Purus Song': nationalization and tribalization in southwestern Amazonia," Tipiti, 4, p. 271-294.

2012 "The Piro canoe: a preliminary ethnographic account," Journal de la Société des américanistes, 98 (1), p. 39-61.

2013 "Autodenominations: an ethnographer's account from Peruvian Amazonia," Tipiti, 11, p. 45-57.

GuERrEIro Antonio

2015 Ancestrais e suas sombras. Uma etnografia da Chefia Kalapalo e seu ritual mortuário, UNICAMP, Campinas.

HeInE Bernd

1997 Possession. Cognitive sources, forces and grammaticalization, Cambridge University Press, Cambridge.

Hugh-Jones Stephen

2001 "The gender of some Amazonian gifts: an experiment with an experiment," in Thomas Gregor, and Donald Tuzin (eds.), Gender in Amazonia and Melanesia. An exploration of the comparative method, University of California Press, Berkeley, p. 245-278.

KANTOROWICZ Ernst

1957 The King's two bodies, Princeton University Press, Princeton.

Kensinger Kenneth

1995 How real people ought to live. The Cashinahua of Eastern Peru, Waveland Press, Prospect Heights.

KoHN Eduardo

2013 How forests think. Toward an anthropology beyond the human, University of California Press, Berkeley.

LABIAK Araci Maria

2007 Frutos do Céu, Frutos da Terra. Aspectos da Cosmologia Kanamari no Warapekom, EDUA, Manaus.

LÉvi-STRAuss Claude

1985 La Potière jalouse, Plon, Paris.

Maizza Fabiana

2014 "Sobre as crianças-plantas: o cuidar e o seduzir no parentesco jarawara," Mana. Estudos de Antropologia Social, 20 (3), p. 491-518.

MALINOwski Bronislaw

1923 The problem of meaning in primitive languages, Harcourt, Brace \& World, New York.

1935 Coral gardens and their magic, Vol. II, George Allen \& Unwin, London. 
Matos Beatriz

2014 A visita dos espíritos: ritual, história e transformação entre os Matses da Amazônia brasileira', Ph.D. Thesis, Social Anthropology, Universidade Federal do Rio de Janeiro.

McCallum Cecilia

2001 Gender and sociality in Amazonia. How real people are made, Berg Press, Oxford.

[Overing] Kaplan

1975 The Piaroa. A people of the Orinoco Basin, Clarendon Press, Oxford.

1977 "Comments (Symposium 'Social time and social space in lowland South American societies')," Actes du XLII Congrès international des américanistes, [Paris, 2-9 septembre 1976], Société des américanistes, Paris, vol. II, p. 387-394.

2003 "In praise of the everyday: trust and the art of social living in an Amazonian community," Ethnos, 68, p. 293-316.

RIVAL Laura

1993 "The growth of family trees: understanding Huaroani perceptions of the forest," Man (N.S.), 28, p. 635-652.

SAPIR Edward

1921 Language, Brace and World, Harcourt.

SEEger Anthony

1981 Nature and society in Central Brazil. The Suyá Indians of Mato Grosso, Harvard University Press, Cambridge.

Seeger Anthony, Roberto DaMatta, and Eduardo Viveiros de Castro

1979 “A construção da pessoa nas sociedades indígenas brasileiras," Boletim do Museu Nacional, 32, p. 2-19.

SHIRATORI Karen

2018 "O olhar envenenado: a metafísica vegetal jamamadi," Ph.D. Thesis, Social Anthropology, Universidade Federal do Rio de Janeiro.

TAYLOR Anne-Christine

1996 "The soul's body and its states: an Amazonian perspective on the nature of being human," Journal of the Royal Anthropological Institute, 2, p. 201-215.

VILAÇA Aparecida

1992 Comendo como gente. Formas do canibalismo Wari', Editora UFRJ, Rio de Janeiro.

2005 "Chronically unstable bodies: reflections on Amazonian corporalities," Journal of the Royal Anthropological Institute, 11, p. 445-464.

Viveiros de CAStro Eduardo

1996 "Os pronomes cosmológicos e o perspectivismo ameríndio," Mana. Estudos de Antropologia Social, 2 (2), p. 115-144. 